\title{
HERITABILITY OF HYGIENIC BEHAVIOUR IN GREY HONEY BEES (Apis mellifera carnica)
}

STANIMIROVIĆ Z, STEVANOVIĆ JEVROSIMA, MIRILOVIĆ M and STOJIĆ V

University of Belgrade, Faculty of Veterinary Medicine, Serbia

(Received 3. May 2008)

Breeding grey A. m. carnica queens for hygienic behaviour is beneficial for commercial beekeeping in Serbia, since hygienic behaviour is associated with the resistance to the mite Varroa destructor, as well as to American foulbrood and chalkbrood. In this work, heritability of hygienic behaviour was analysed in autochthonous grey $A$. $m$. carnica honey bees from Šumadija region in order to ascertain if the expression of their hygienic behaviour could be enhanced through selective breeding. Heritability of hygienic behaviour was monitored through three queen generations and estimated by one-parent-offspring regression method (motherdaughter regression method). The heritability values for hygienic behaviour were $h^{2}=0.63 \pm 0.02$ in relationship between daughter queens (F1s) and breeder mother queens (Ps), $h^{2}=0.45 \pm 0.01$ in relationship between grand-daughter queens (F2s) and $P s$ and $h^{2}=0.44 \pm 0.02$ in relationship between $F 2 s$ and $F 1 s$. These results show that the expression of hygienic behaviour through selective breeding could be enhanced and the best results could be achieved in the F1 generation. It is important to emphasize that the F1 colonies bred for hygienic behaviour in our stydy suffer no apparent costs in reproductive and productive performances.

Key words: Apis mellifera carnica, heritability of hygienic behaviour

\section{INTRODUCTION}

Beekeeping with Apis mellifera L. bees is endangered worldwide by the ectoparasitic mite Varroa destructor Anderson and Trueman. Suppression of $V$. destructor with acaricides is followed by numerous problems: loss of efficacy after prolonged use due to the development of mite resistance (reviewed by Milani, 1999), the propagation of susceptible colonies by beekeepers, the occurrence of acaricide residues in honey, wax and other bee products (Wallner, 1999; Bogdanov, 2006), and increased beekeeping costs (Oldroyd, 1999). In addition, detrimental effects on bees have been reported as a consequence of acaricide treatment (Pettis et al., 2004) and organic acids treatment (Nozal et al., 2003; Gregorc et al., 2004; Gregorc and Smodiš-Škerl, 2007). Thus, a more sustainable 
solution to the mite problem is to select and breed lines of honey bees that show natural mechanisms of resistance to the mite (Stanimirović et al., 2005a; Ibrahim and Spivak, 2006). Hygienic behaviour is one of several known mechanisms of resistance against $V$. destructor (Peng et al., 1987; reviewed in Boecking and Spivak, 1999). Hygienic honey bee workers are able to detect, uncap the wax covering over the brood cells and remove diseased larvae and pupae out of their cells. The bees uncap and remove the majority of mite-infested cells 4-7 d after the cell is capped (Spivak 1996, Thakur et al. 1997), when offspring of the invading foundress mite are developing on the capped pupa. The removal of infested pupae thus limits the number of offspring of the mites by interrupting their reproductive cycle (Fries et al. 1994). Hygienic behaviour is predominantly performed by the middle-aged worker bees (15- to 20-day-old bees) that have not yet begun foraging and about $18 \%$ of the bees in the colony are actually involved in the task at any given time (Arathi et al., 2000).

Other resistance mechanisms against the mites including grooming behaviour, in which adult bees remove mites from themselves or from nestmates, damaging the mites in the process (Boecking and Spivak, 1999); as well as an unknown physiological effect of either worker pupae or adult bees in some colonies that reduces mite reproduction, the trait called Suppression of Mite Reproduction-SMR (Harbo and Hoopingarner, 1997; Harris and Harbo, 1999). The SMR line showed promise as stock with a good resistance mechanism against $V$. destructor. However, many SMR colonies suffered from poor brood viability and low honey production and beekeepers were unwilling to test the pure SMR line in their colonies (Ibrahim et al., 2007).

This study examines the possibility to enhance the expression of hygienic behaviour through selective breeding in autochthonous grey $A$. $m$. carnica honey bees from Šumadija. Having in mind that selective breeding can proceed only with the characteristics that are heritable $\left(h^{2}>0.25\right)$, the purpose of this study is to measure the heritability of hygienic behaviour in those bees.

\section{MATERIAL AND METHODS}

The experiments were conducted from April 2004 to July 2006 in an apiary near the city of Gornji Milanovac, Šumadija, Serbia). The expression of honey bee hygienic behavior was measured using a modification of the pin-killed brood (PKB) assay, described by Keffus et al. (1996). The frame containing a capped brood was chosen from each experimental colony. On each frame, square sampling area of comb $(5 \times 6 \mathrm{~cm})$ was marked with a wire template and all cells inside the marked area were punctured with a fine pin to kill the brood. The frames were re-introduced in their hives and were inspected 24 hours later to count the number of cells that had been completely uncapped and cleaned by the bees. Colonies that removed $>95 \%$ PKB within $24 \mathrm{~h}$ were considered super-hygienic, those that removed $90-95 \%$ PKB in the same interval were considered hygienic, whilst non-hygienic were colonies that removed $<90 \%$ PKB within $24 \mathrm{~h}$ (Stanimirovic et al. 2002). Only those super-hygienic colonies that had also good reproductive and productive features were considered breeder colonies and used 
Acta Veterinaria (Beograd), Vol. 58. No. 5-6, 593-601, 2008.

Stanimirović $Z$ et al.: Heritability of hygienic behaviour

in grey honey bees (Apis mellifera carnica)

for rearing queens during the experiment. Each queen was marked with enamel paint and number on the thorax. The study began with 8 commercial unselected lines of the grey carniolan bees. Ten daughter queens were propagated from the mother queen in each line. Those 80 queens represented unselected parental $(P)$ queens and their colonies were tested for hygienic behavior. Eight queens (those whose colonies showed best results), were selected as breeder mother queens (Ps queens), and 80 daughter queens ( $\mathrm{F} 1$ queens) were propagated from them and tested for hygienic behavior. The best eight daughter queens were selected ( $\mathrm{F} 1 \mathrm{~s}$ queens) and used to rear 80 grand-daughters queens ( $\mathrm{F} 2$ queens). Their colonies were also tested for hygienic behavior and the best eight granddaughters queens were selected (F2s queens). Queens were mated naturally with the high quality drones reared according to the method of Laidlaw and Page (1997).

Heritability of hygienic behaviour (monitored through three queen generations) was estimated by one-parent-offspring regression method (motherdaughter regression method). The following equations were used for heritability calculation:

$\mathrm{b}_{\mathrm{yx}}=\frac{\Sigma \mathrm{xy}-\frac{(\Sigma \mathrm{x})(\Sigma \mathrm{y})}{\mathrm{n}}}{\Sigma \mathrm{x}^{2}-\frac{(\Sigma \mathrm{x})^{2}}{\mathrm{n}}} \quad \mathrm{b}_{\mathrm{zx}}=\frac{\Sigma \mathrm{xz}-\frac{(\Sigma \mathrm{x})(\Sigma \mathrm{z})}{\mathrm{n}}}{\Sigma \mathrm{x}^{2}-\frac{(\Sigma \mathrm{x})^{2}}{\mathrm{n}}} \quad \mathrm{b}_{\mathrm{zy}}=\frac{\Sigma \mathrm{yz}-\frac{(\Sigma \mathrm{y})(\Sigma \mathrm{z})}{\mathrm{n}}}{\Sigma \mathrm{y}^{2}-\frac{(\Sigma \mathrm{y})^{2}}{\mathrm{n}}}$

$x$ - mean value of hygienic behaviour of Ps queen,

$y$ - mean value of hygienic behaviour of $F 1$ s queen,

$\mathrm{z}$ - mean value of hygienic behaviour of F2s queen,

$\mathrm{n}-$ No. of queens,

$b_{y x}$ - heritability of hygienic behaviour in relationship F1s - Ps,

$\mathrm{b}_{\mathrm{zx}}$ - heritability of hygienic behaviour in relationship F2s - Ps,

$\mathrm{b}_{\mathrm{zy}}-$ heritability of hygienic behaviour in relationship F2s $-\mathrm{F} 1 \mathrm{~s}$.

Statistical analysis, consisting of one-way analysis of variance (ANOVA) followed by Tukey pairwise multiple comparisons, were performed using GraphPade prism 4.0.

\section{RESULTS}

Descriptive characteristics of hygienic behaviour expression in colonies with unselected queens are summarized in Table 1. Following mean values of hygienic behaviour, colonies with P queens appeared hygienic $(92.67 \%)$, colonies with $\mathrm{F} 1$ queens were super-hygienic $(95.31 \%)$, whilst colonies with F2 queens were non-hygienic $(88.24 \%)$. Small coefficient of variation $(\mathrm{CV}<8 \%)$ indicate high intergroup homogeneity of the colony hygienic behaviour within each queen generation, P, F1 and F2 (Table 1).

ANOVA showed a significant differences $(F=46.15 ; p<0.001)$ in hygienic behaviour among all analysed colonies with unselected queens. Tukey's test 

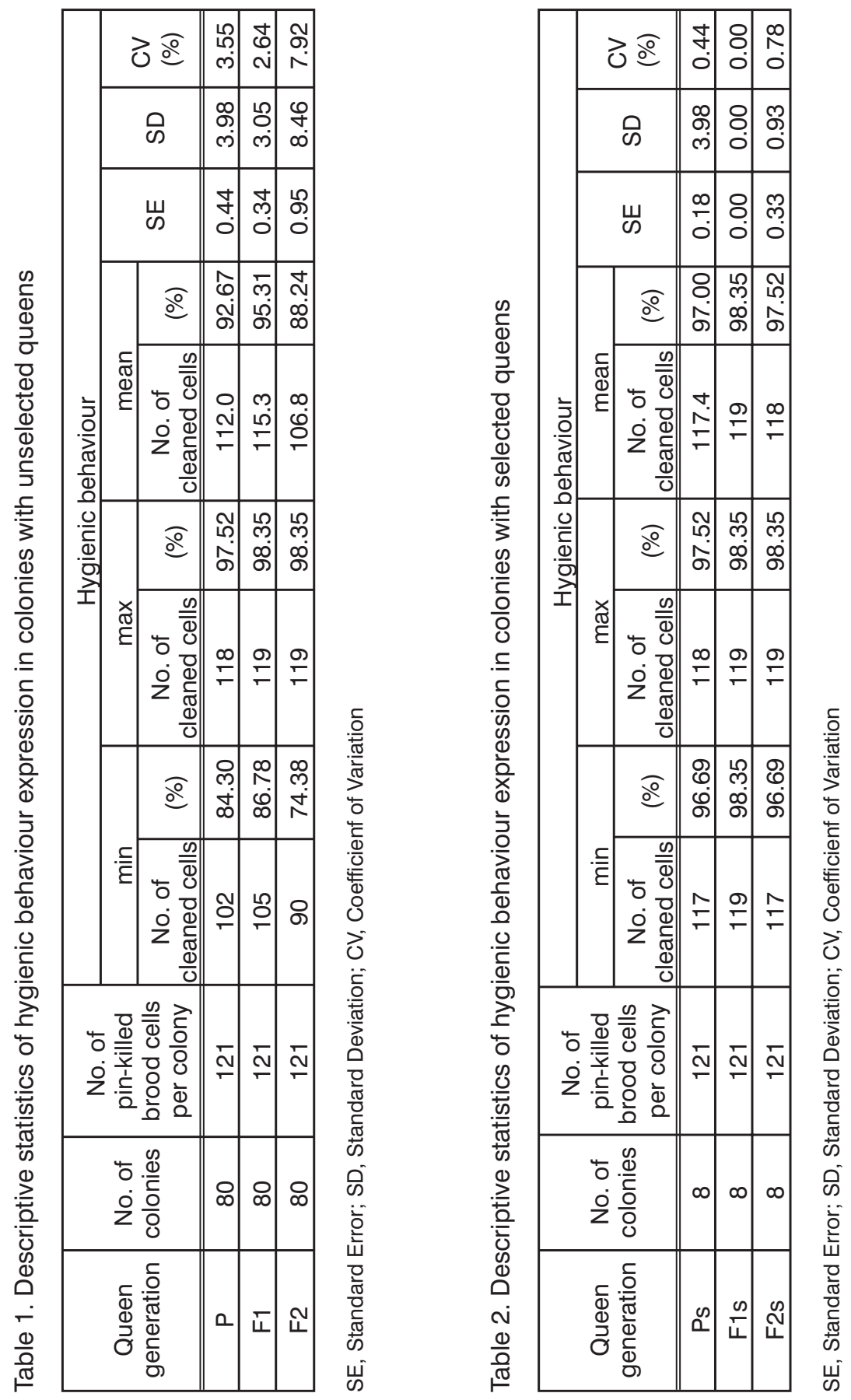
Acta Veterinaria (Beograd), Vol. 58. No. 5-6, 593-601, 2008.

indicated a significant diference $(p<0.001)$ in means between groups (queen generations), i.e. between $P$ and $F 1$ queens $(Q=5.22)$, between $P$ and $F 2$ queens $(\mathrm{Q}=8.25)$ and between $\mathrm{F} 1-\mathrm{F} 2$ queens $(\mathrm{Q}=13.47)$.

Descriptive characteristics of hygienic behaviour expression in colonies with selected queens are summarized in Table 2. Hygienic behaviour in all colonies with selected queens was super-hygienic with the mean value of 97.00 , 98.35 and $97.52 \%$ in colonies with Ps, F1s and F2s queens, respectively. Small coefficients of variation $(\mathrm{CV}<1 \%)$ indicate high intergroup homogeneity of the colony hygienic behaviour within each queen generation, Ps, F1s and F2s (Table 2).

The heritability values for hygienic behaviour were $h^{2}=0.63 \pm 0.02$ in relationship F1s $-\mathrm{Ps}, h^{2}=0.45 \pm 0.01$ in relationship F2s $-\mathrm{Ps}$ and $h^{2}=0.44 \pm 0.02$ in relationship F2s - F1s.

In addition, colonies bred for hygienic behaviour had similar populations and brood areas and produced as much honey as the unselected colonies and suffer no apparent additional costs in reproductive and productive performances.

\section{DISCUSSION}

Breeding honey bees (Apis mellifera L.) for resistance to the injurious parasitic mite Varroa destructor Anderson and Trueman (2000) has become a priority in apiculture almost a decade ago. A reasonable goal for a breeding program is to select honey bees that have heritable mechanisms of defense against the mites that allow them to tolerate infestation longer than unselected colonies before chemical treatments are required (Spivak and Reuter, 2001a). This is especially important in Serbia because beekeepers still use to treat their bees with practically all chemicals available and many of them have a genotoxic and clastogenic potential (Stanimirovic et al., 2005b, 2007). Most often, the beekeepers in Serbia use highly effective pesticides: either the synthetic pyrethroids: fluvalinate and flumetrine or more recently, amitraz and cymiazole hydrochloride. However, after experience with acaricide-resistant mites, many beekeepers are aware that prolonged use of acaricides is not a sustainable practice and that it is much better to implement more integrated control practices. However, the foundation of any integrated program is the availability of selected lines of bees that demonstrate resistance mechanisms against the mites. These lines should retain genetic variability, and should have no fitness costs, such as reduced honey production or susceptibility to diseases, that may be associated with the traits that confer resistance (Bailey, 1999). We chose to analyse the heritability of one behavioral mechanism of defense, hygienic behavior, because it is known to be not only a mechanism of defense against $V$. destructor, but also the primary mode of resistance against two diseases of honey bee brood, American foulbrood and chalkbrood (Boecking and Spivak, 1999; Spivak and Reuter, $2001 a, b)$ and thus is of broad economic interest in apiculture. In this study, heritability of hygienic behaviour was measured in autochthonous grey $A . m$. carnica honey bees. The possibility to enhance the expression of hygienic behaviour through selective breeding is discussed. First, the expression of the 
hygienic behaviour was measured in 240 colonies with unselected queens and 24 colonies with selected queens. The results indicated high potential of hygienic behaviour of analysed colonies, with the highest values in F1 generation, in both unselected queens (95.31\%) and selected queens (98.35\%). Thus, the heterotic effect was observed for the hygienic behaviour in our study. Until now, there were only a few investigations of heterosis in honey bees. In an early study of Cale and Gowen (1956) heterotic effects in queen bees were demonstrated for oviposition rate and honey yield. However, in investigations of Oldroyd and Goodman (1988), heterotic effects appeared for longevity of $F 1$ queens and for brood production, but not for honey yield. In our study, F1 queens showed very marked heterosis for hygienic behaviour expression. These findings are expected since egg production and longevity of the queen are characters largely dependent on the queen's own genotype, and honey yield and hygienic behaviour are characters dependent on the vigor and well being of the queen's worker progeny. Honey yield and hygienic behaviour consequently differs from egg production in being influenced by the genome of the drones to which the queen is mated. In addition, polyandry (multiple mating) of queens increase genetic diversity and contributes to heterosis even in such conditions as in our study where queens were mated with the same pool of reared high quality drones, but they were allowed to fly and mate with whatever drones they encountered. The heterosis effect in our study decreased in the F2 generation in both unselected queens (88.24\%) or in selected queens (97.52\%). These results are in accordance with the findings of Lee (2000) that sexually reproducing species heterosis erodes rapidly due to segregation and does not confer permanent fitness benefits.

Heritability $\left(h^{2}\right)$ is the proportion of the observed variance (among a group of bee colonies in this case) for which differences in heredity are responsible. Heritability estimates vary between 0 and 1 . If a characteristic has an $h^{2}$ close to 1 , then the characteristic can be changed rapidly by selective breeding. If $h^{2}=0$, selective breeding will fail. For a particular inherited trait, a high $h^{2}$ value $(>0.6)$ indicates a greater influence of genetic factors while a lower value $(<0.3)$ indicates a stronger influence of environmental factors. As a general rule, selective breeding can proceed if $h^{2}$ is $>0.25$. Heritability may be estimated by comparing parent and offspring traits. Parent-offspring designs compare phenotypic variance between parents and offspring. Parent-offspring regression is one of the most commonly used methods. A specific phenotypic trait is measured for both the parent and the offspring at the same age and compared using regression. The slope of regression between offspring and parents will tell you about resemblance between relatives (narrow sense heritability, $h^{2}$ ). A one parent-offspring is a comparison between either the mother or father and the offspring and gives an estimate of half of the narrow sense heritability. In our study, only mothers's value is used (mother-daughter regression method). Using the same method, Boecking and Drescher (1992) found the heritability value $h^{2}=0.18 \pm 0.27$ for the removal of brood experimentally infested with one living mite per cell and $h^{2}=0.36 \pm 0.30$ for the removal of dead brood (killed using the pin-killed brood assay). However, Harbo and Harris (1999) calculated the heritability of hygienic behaviour to be $h^{2}=0.65 \pm 0.61$. This value and the values we obtained in current study 
Acta Veterinaria (Beograd), Vol. 58. No. 5-6, 593-601, 2008.

$\left(h^{2}=0.63 \pm 0.02 ; 0.45 \pm 0.01\right.$ and $0.44 \pm 0.02$ in relationship F1s $-\mathrm{Ps}, \mathrm{F} 2 \mathrm{~s}-\mathrm{Ps}$ and F2s - F1s, respectively) indicate that hygienic behaviour is heritable in autochthonous grey $A$. $m$. carnica honey bees from Šumadija. Thus, breeding those honey bees for hygienic behaviour is reasonable. The results also show that the expression of hygienic behaviour through selective breeding could be enhanced in analysed bees and the best results could be achieved in F1 generation. It is important to emphasize that the F1 colonies bred for hygienic behaviour in our stydy had similar populations and brood areas, produced as much honey as the unselected colonies, suffered no apparent fitness costs, and performed as well, if not better, than commercial lines not bred for hygienic behaviour which is in accordance with previous findings of Spivak and Reuter (1998, 2001a) and the findings of Pejovic (2008). Breeding grey A. m. carnica queens for hygienic behaviour is beneficial for commercial beekeeping in Serbia, since hygienic behaviour is associated with the resistance to Varroa destructor, as well as to American foulbrood and chalkbrood. Consequently, colonies bred for hygienic behaviour require less or no acaricide treatment, beekeeping operating costs are lower and risk of contaminating honey and other hive products is decreased (Spivak and Reuter, 2001a). Nevertheless, recent investigations of Ibrahim et al. (2007) that should not be disregarded have shown that selecting colonies for hygienic behaviour does in fact reduce mite levels compared to unselected colonies, but the regression of mites on adult bees and in worker brood as a function of hygienic behavior indicated that expressing hygienic behavior is not sufficient for mite resistance. Thus, grooming behaviour, as another natural mechanisms of resistance against $V$. destructor, should be investigated in autochthonous grey A. $m$. carnica honey bees from Sumadija, as well as the possibility to enhance the expression of that behaviour through selective breeding.

ACKNOWLEDGEMENTS:

This study was supported by the Ministry of Science, Republic of Serbia (Grant No. 143022).

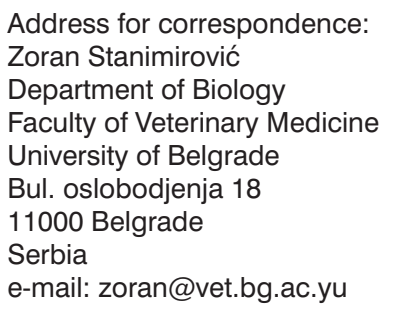

\section{REFERENCES}

1. Arathi HS, Burns I, Spivak M, 2000, Ethology of hygienic behaviour in the the honey bee, Apis mellifera (Hymenoptera: Apidae): Behavioural repertoire of hygienic bees, Ethology, 106, 36579.

2. Bailey $L, 1999$, The quest for a super-bee, Bee World, 80, 55-60. 
3. Boecking O, Drescher W, 1992, The removal responses of Apis mellifera L colonies to brood in wax and plastic cells after artificial and natural infestation with Varroa jacobsoni Oud and to freezekilled brood, Exp Appl Acarol, 16, 321-9.

4. Boecking O, Spivak M, 1999, Behavioral defenses of honey bees against Varroa jacobsoni Oud Apidologie, 30, 141-58.

5. Bogdanov S, 2006, Contaminants in bee products, Apidologie, 37, 1-18.

6. Cale GH, Gowen JW, 1956, Heterosis in the honey bee (Apis mellifera L), Genetics, 41, 292-303.

7. Fries I, Camazine S, Sneyd J, 1994, Population dynamics of Varroa jacobsoni: a model and a review, Bee World, 75, 5-28.

8. Gregorc A, Smodiš Škerl MI, 2007, Toxicological and immunohistochemical testing of honeybees after oxalic acid and rotenone treatments, Apidologie, 38, 296-305.

9. Gregorc A, Pogacnik A, Bowen ID, 2004, Cell death in honeybee (Apis mellifera) larvae treated with oxalic or formic acid, Apidologie, 35, 453-60.

10. Goode K, Huber Z, Mesce KA, Spivak M, 2006, Hygienic behavior of the honey bee (Apis mellifera) is independent of sucrose responsiveness and foraging ontogeny, Horm Behav, 49, 391-7.

11. Harbo JR, Hoopingarner RA, 1997, Honey bees (Hymenoptera: Apidae) in the United States that express resistance to Varroa jacobsoni (Mesostigmata: Varroidae), J Econ Entomol, 90, 893-8.

12. Harbo JR, Harris JW, 1999, Heritability in honey bees (Hymenoptera, Apidae) of characteristics associated with resistance to Varroa jacobsoni (Mesostigmata, Varroidae). J Econ Entomol, 92 , 261-265.

13. Harris JW, Harbo JR, 1999, Low sperm counts and reduced fecundity of mites in colonies of honey bees (Hymenoptera: Apidae) resistant to Varroa jacobsoni (Mesostigmata: Varroidae), J Econ Entomol, 92, 83-90.

14. Ibrahim A, Spivak M, 2006, The relationship between hygienic behavior and suppression of mite reproduction as honey bee (Apis mellifera) mechanisms of resistance to Varroa destructor, Apidologie, 37, 31-40.

15. Ibrahim A, Reuter GS, Spivak M, 2007, Field trial of honey bee colonies bred for mechanisms of resistance against Varroa destructor, Apidologie, 38, 67-76.

16. Kefuss J, Taber S, Vanpoucke J, Rey F, 1996, A practical method to test for disease resistance in honey bees, Am Bee J, 136, 31-2.

17. Laidlaw HH Jr, Page RE Jr, 1997, Queen rearing and bee breeding, Wicwas, Cheshire, Conn, USA.

18. Lee CE, 2002, Evolutionary genetics of invasive species, Trends Ecol Evol, 17, 386-91.

19. Milani N, 1999, The resistance of Varroa jacobsoni Oud to acaricides, Apidologie, 30, $229-34$.

20. Nozal MJ, Bernal JL, Gómez LA, Higes M, Meana A, 2003, Determination of oxalic acid and other organic acids in honey and in some anatomic structures of bees, Apidologie, 34, 181-8.

21. Oldroyd BP, 1999, Coevolution while you wait: Varroa jacobsoni, a new parasite of western honeybees, Trends Ecol Evol, 14, 312-5.

22. Oldroyd BP, Goodman RD, 1988, Inbreeding and heterosis in queen bees in relation to brood area and honey production, Austr J Agricul Res, 39, 959-64.

23. Pettis JS, Collins AM, Wilbanks R, Feldlaufer MF, 2004, Effects of coumaphos on queen rearing in the honey bee, Apis mellifera, Apidologie, 35, 605-10.

24. Pejović $D, 2008$, Investigation of the heritability of hygienic and grooming behaviour of grey honey bee Apis mellifera carnica and the influence of these features on reproductive and productive traits of honey bee colonies, PhD dissertation (in serbian), Univ Belgrade, Serbia.

25. Peng YS, Fang Y, Xu S, Ge L, Nasr ME, 1987, Response of foster Asian honey bee (Apis cerana Fabr) colonies to the brood of European honey bee (Apis mellifera $\mathrm{L}$ ) infested with parasitic mite Varroa jacobsoni Oudemans, J Invertebr Pathol, 49, 259-64.

26. Spivak M, 1996, Hygienic behavior and defense against Varroa jacobsoni, Apidologie, 27, 245-60.

27. Spivak M, Reuter GS, 1998, Performance of hygienic honey bee colonies in a commercial apiary, Apidologie, 29, 291-302.

28. Spivak M, Reuter GS, 2001a, Varroa destructor infestation in untreated honey bee (Hymenoptera: Apidae) colonies selected for hygienic behavior, J Econ Entomol, 94, 326-31. 
Acta Veterinaria (Beograd), Vol. 58. No. 5-6, 593-601, 2008.

29. Spivak M, Reuter GS, 2001b, Resistance to American foulbrood disease to honey bee colonies Apis mellifera bred for hygienic behavior, Apidologie, 32, 555-65.

30. Stanimirović Z, Pejović D, Stevanović Jevrosima, Vučinić Marijana, Mirilović M, 2002, Investigations of hygienic behaviour and disease resistance in organic beekeeping of two honeybee ecogeographic varieties from Serbia, Acta Vet, 52, 169-80.

31. Stanimirović Z, Stevanovic J, Ćirković D, 2005a, Behavioural defenses of the honey bee ecotype from Sjenica - Pester against Varroa destructor, Acta Vet, 55, 69-82.

32. Stanimirovic Z, Stevanovic J, Jovanovic S, Andjelkovic M, 2005b, Evaluation of genotoxic effects of Apitol ${ }^{\circledR}$ (cymiazole hydrochloride) in vitro by measurement of sister chromatid exchange. Mutat Res, 588, 152-7.

33. Stanimirovic Z, Stevanovic Jevrosima, Bajic V, Radovic I, 2007, Evaluation of genotoxic effects of fumagillin (dicyclohexylamine) by citogenetic tests in vivo, Mutat Res, 628, 1-10.

34. Thakur RK, Bienefeld K, Keller R, 1997, Varroa defense behavior in A mellifera carnica, Am Bee J, 137, 143-8.

35. Wallner K, 1999, Varroacides and their residues in bee products, Apidologie, 30, 235-48.

\section{HERITABILNOST HIGIJENSKOG PONAŠANJA SIVE MEDONOSNE PČELE (Apis mellifera carnica)}

\section{STANIMIROVIĆ Z, STEVANOVIĆ JEVROSIMA, MIRILOVIĆ M i STOJIĆ V}

\section{SADRŽAJ}

Odgajanje matica sive medonosne pčele $A$. $m$. carnica sa ispoljenim higijenskim ponašanjem od velikog je značaja za komercijalno pčelarenje u Srbiji, obzirom da je higijensko ponašanje povezano sa otpornošću prema krpelju Varroa destructor, kao i prema izazivačima bolesti američke truleži pčelinjeg legla i krečnog legla. U ovom radu, ispitivana je heritabilnost higijenskog ponašanja kod autohtone sive medonosne pčele $A$. $m$. carnica iz Šumadije da bi se utvrdilo da li ispoljenost higijenskog ponašanja kod tih pčela može da se poveća putem selektivnog gajenja. Heritabilnost higijenskog ponašanja praćena je kroz tri generacije matica i procenjivana metodom regresije jedan roditelj-potomak (metoda regresije majka-ćerka). Vrednosti koeficijenta heritabilnosti higijenskog ponašanja bile su $h^{2}=0,63 \pm 0,02$ između ćerki matica (F1s) i majki matica (Ps), $h^{2}=0,45 \pm 0,01$ između unuka matica (F2s) i Ps, i $h^{2}=0.44 \pm 0.02$ između F2s i F1s. Ovi rezultati pokazuju da ispoljenost higijenskog ponašanja kod analiziranih pčela može biti povećana, kao i da se najbolji rezultati mogu postići u F1 generaciji. Pri tome je značajno istaći da kod društava F1 generacije odgajenih na higijensko ponašanje u našem radu nije bilo nikakvih negativnih posledica u pogledu reproduktivnih $\mathrm{i}$ produktivnih sposobnosti. 